\title{
LEARNING OF REACTION RATE WITH NESTED CURRICULAR ARRANGEMENT TO IMPROVE CRITICAL THINKING SKILLS AND UNDERSTANDING THE CONCEPT OF STUDENTS IN ACTIVE- REFLECTIVE LEARNING
}

\author{
Maria Fransiska Mei Santi Omes dan Suyono \\ Jurusan Kimia FMIPA Universitas Negeri Surabaya
}

Email: omesfransiska@gmail.com

\begin{abstract}
This study aims to evaluate the learning rate of reactions by nested curricular arrangement. This learning is designed using the inquiry model. The learning process was attended by 34 XI MIA 7 students of SMAN 1 Manyar, Gresik, East Java. The objects in this study are critical thinking skills and students' understanding of the concept of active-reflective learning styles. This study was designed using "pre-experimental design," using one group pretest-posttest design. Analysis of critical thinking skills is done using t-tests and students' understanding of concepts is done using the Wilcoxon test. Learning is carried out for 2 times with the smallest percentage of performance in each meeting that is $80 \%$. This shows the learning process is going well. Critical thinking skills that are trained and measured consist of 4 elements, namely: interpretation, inference, analysis, and explanation with a calculated value of $t=26.991$. This value indicates that $t$ arithmetic $>t$ table. This shows that there are significant differences in students' critical thinking skills before and after learning. In understanding the concept test value of Asymp Sig $=0.00$. This value indicates that the Asymp Sig <0.05. It can be concluded that there is an increase in the conceptual understanding of active-reflective learning style students after following the reaction rate learning by nested curricular structuring.
\end{abstract}

Keywords: Nested, inquiry, active-reflective learning style, critical thinking skills

\section{PENDAHULUAN}

Kemajuan di abad-21 saat ini mempengaruhi berbagai aspek kehidupan manusia, terutama dalam pekerjaan yang saat ini bersifat internasional, multikultural dan saling berhubungan. Sifat ini menuntut manusia untuk bisa memiliki keterampilan-keterampilan penting di abad 21 ini. Keterampilan-keterampilan penting di abad ke-21 mencakup learning to know, learning to do, learning to be dan learning to live togetheryang juga merupakan empat pilar kehidupan. Keterampilan-keterampilan khusus yang perlu dilatih berdasarkan keempat prinsip tersebut diantaranyapemikiran kritis, kemampuan memecahkan masalah, kemampuan komunikasi, kolaborasi, menginovasikan dan mengkreasikan sesuatu, dan berbagai keterampilan lainnya (1).

Pendidikan di Indonesia menggunakan kurikulum 2013. Tujuan kurikulum 2013 ini diantaranya adalah mengembangkan keterampilan berpikir kritis, dimana materi pembelajaran diberikan sampai pada tahap metakognitif. Hal ini juga disebutkan dalam Peraturan Menteri Pendidikan dan Kebudayaan No. 21 Tahun 2016, dimana Taksonomi Bloom mengklasifikasikan tingkat pengetahuan yaitu: faktual, konseptual, prosedural, dan metakognitif sehingga perlu dikuasai mulai tingkat pendidikan dasar hingga tingkat pendidikan menengah. Oleh sebab itu, diperlukan pembelajaran yang dapat melatihkan dan meningkatkan keterampilan-keterampilan tersebut.

Kimia adalah mata pelajaran yang penerapannya terdapat dalam kehidupan seharihari, hanya saja diperlukan kemampuan berpikir yang tinggi untuk dapat mengetahui dan menghubungkan konsep-konsep kimia tersebut pada kehidupan sehari-hari. Salah satu materi kimia yang dapat melatihkan keterampilan berpikir kritis dan kemampuan mengorganisir adalah materi faktor-faktor yang mempengaruhi laju reaksi. Hal ini juga berkaitan dengan karakteristik laju reaksi yang memuat perhitungan 
matematis, grafik dan mencakup multirepresentasi (makroskopik, sub mikroskopik, dan simbolik) (2). Berdasarkankarakteristiktersebut.kemampuan berpikir kritis dan mengorganisir dibutuhkan pada materi laju reaksi. Oleh sebab itu, untuk mencapai kemampuan-kemampuan di atas, terdapat tahapan-tahapan yang harus dilalui siswa, seperti melakukan percobaan. Namun sebelum itu, guru mengajak siswauntuk melakukan pengamatan fenomena alam yang berkaitan dengan laju dari suatu reaksi kimia (3).

Dalam faktanya keterampilan berpikir kritis pada materi kimia tidak selalu mudah untuk dilatihkan. Berdasarkanpenelitian yang dilakukannya, Carisma menyatakan bahwa ada 37\% siswa yang mengatakan bahwa pembelajaran di sekolah masih berpusat kepada guru (4). Selain itu, siswa juga sulit untuk melakukan perumusan masalah, perumusan hipotesis, penentuan variabel, dan analisis suatu masalah. Hal ini juga dapat dibuktikan melalui data persentase penguasaan soal UN materi kimia dari Pusat Penilaian Pendidikan (Puspendik) tahun 2016 yang menyatakan bahwa kemampuan siswa dalam menentukan variabel bebas, variabel kontrol, dan variabel terikat masih sangat rendah yaitu sebesar $37,12 \%$. Persentase ini merupakan persentase terendah untuk semua kemampuan yang diuji pada ujian nasional. Pada tahun 2018, hasil UN dengan indikator materi laju reaksi juga menunjukkan persentase yang cukup rendah yaitu sebesar 50,54\%. Kemampuan dalam menentukan variabel bebas, kontrol, dan variabel terikat ini merupakan salah satu komponen kemampuan berpikir kritis. Rendahnya keterlibatan siswa yang ditandai dengan pembelajaran yang berpusat pada gurumenutup kesempatan siswa dalam meningkatkan keterampilan berpikir kritis(5).

Pembelajaran terpadu tipe nested (tersarang) merupakan pengintegrasian kurikulum dengan menyarangkan beberapa keterampilan belajar yang ingin diajar untuk mencapai materi pelajaran. Keterampilan-keterampilan tersebut meliputi keterampilan berpikir, keterampilan sosial, dan keterampilan organisir.Keterampilanketerampilan yang disarangkandisesuaikandengan karakteristik materi. Sebagai contoh pelajaran IPA dan matematika dapat menyarangkan keterampilan berpikir dan keterampilan organisir (6). Pembelajaran tipe ini dapat lebih menghemat waktu dalam proses pengajaran karena guru dapat memadukan beberapa keterampilan berpikir maupun sosial sekaligus dalam suatu pembelajaran dengan memfokuskan pada isi pelajaran.
Pembelajaran yang baik tidak hanya melihat model pembelajaran yang sesuai dengan materi saja, namun juga perlu melihat karakteristik dari peserta didik yang mengikuti pembelajaran. Salah satu karakteristik yang dapat dilihat adalah gaya belajar. Terdapat 10 dimensi gaya belajar dilihat dari persepsi, input, organisasi, proses, dan pemahaman belajar siswa. Dilihat dari segi proses belajar, ada 2 dimensi gaya belajar yaitu aktif dan reflektif (7). Pembelajaran materi laju reaksi yang ingin memperoleh konsep dapat menerapkan gaya belajar dimensi aktif reflektif. Dalam satu kelas tidak ada siswa yang cenderung ke salah satu dimensi saja (8). Pada dimensi gaya belajar aktif siswa melakukan eksperimen untuk menguji informasi yang diperoleh, kemudian menganalisis, mendiskusikan, dan menjelaskannya, sedangkan gaya belajar siswa reflektif cenderung belajar dengan cara memikirkan sesuatu, lebih menyukai bekerja sendiri atau dengan seorang rekan yang sudah cukup dekat. Berdasarkan hal tersebut pembelajaran pada materi laju reaksi dirancang dengan menggunakan pola nested untuk meningkatkan keterampilan berpikir kritis dan pemahaman konsep siswa bergaya belajar aktif reflektif.

\section{METODE}

Jenis penelitian ini adalah pra-eksperimen denganone group pretest-posttest design yaitu eksperimen yang dilakukan hanya pada satu kelompok saja, tanpa adanya kelompok pembanding. Sasaran penelitian ini adalah siswa kelas XI MIA 7 SMAN 1 Manyar.

Analisis keterampilan berpikir kritis dilakukan dengan menggunakan uji t, sedangkan uji pemahaman konsep pada penelitian ini dilakukan dengan menggunakan uji Wilcoxon. Kedua ujiini digunakan untuk menguji hipotesis. Hipotesis yang diuji pada penelitian ini adalah:

Ho : tidak ada perbedaan rerata kemampuan berpikir kritis siswa sebelum dansesudah pembelajaran laju reaksi dengan penataan kurikuler nested.

Ha : terdapat perbedaan rerata kemampuan berpikir kritis siswa sebelum dan sesudah pembelajaran laju reaksi dengan penataan kurikuler nested.

Uji t dilakukan dengan menggunakan rumus:

$$
\mathrm{t}=\frac{\sum D}{\sqrt{n \sum D^{2}-\left(\sum D\right)^{2} /(N-1)}}
$$

Kemudian harga $\mathrm{t}$ hitung dibandingkan dengan harga $t$ tabel (9). Jika harga $t$ hitung $<t$ tabel maka Ho diterima dan jika $t$ hitung $\geq t$ tabel maka Ho ditolak. 
Pada uji Wilcoxon kriteria keberhasilandidasarkanpada nilai Asymp, Sig dalam program SPSS dimana;

a) Jika Asymp, Sig< $\alpha$ maka $\mathrm{H}_{0}$ ditolak

b) Jika Asymp, Sig $\geq \alpha$ maka $\mathrm{H}_{0}$ diterima (10).

Hipotesis yang diuji untuk pemahaman konsep adalah:

Ho : pembelajaran laju reaksi dengan penataan kurikuler nested tidak berpengaruh terhadap pemahaman konsep siswa secara signifikan

$\mathrm{Ha}$ : pembelajaran laju reaksi dengan penataan kurikuler nested dapat berpengaruh terhadap pemahaman konsep siswa secara signifikan

Analisis dengan menggunakan uji $\mathrm{t}$ maupun Wilcoxon pada penelitian ini dibantu dengan menggunakan aplikasi SPSS.

Analisis keterlaksanaan pembelajaran dilakukan dengan menggunakan percentage of agreement dari pengamat 1 dengan pengamatan 2 , pengamat 1 dengan pengamat 3 , dan pengamat 2 dengan pengamat 3. Pembelajaran dikatakan terlaksana dengan baik pada setiap aspek apabila percentage of agreement mencapai $\geq 75 \%$.

Rumus percentage of agreement :

Percentage of agreement $=100\left(1-\frac{\mathrm{A}-\mathrm{B}}{\mathrm{A}+\mathrm{B}}\right)$

\section{HASILDAN PEMBAHASAN}

\section{Identifikasi Gaya Belajar}

Pada penelitian ini, sebelum pembelajaran dimulai dilakukan indentifikasi gaya belajar siswa dengan menggunakan menggunakan instrumen yang telah dikembangkan oleh Aryungga (2014) (11). Identifikasi gaya belajar ini dilakukan dengan tujuan agar memudahkan guru dalam mengatur dan merencanakan proses pembelajaran yang sesuai dengan tiap gaya belajar. Hasil yang diperoleh ditunjukkan pada Gambar 1.

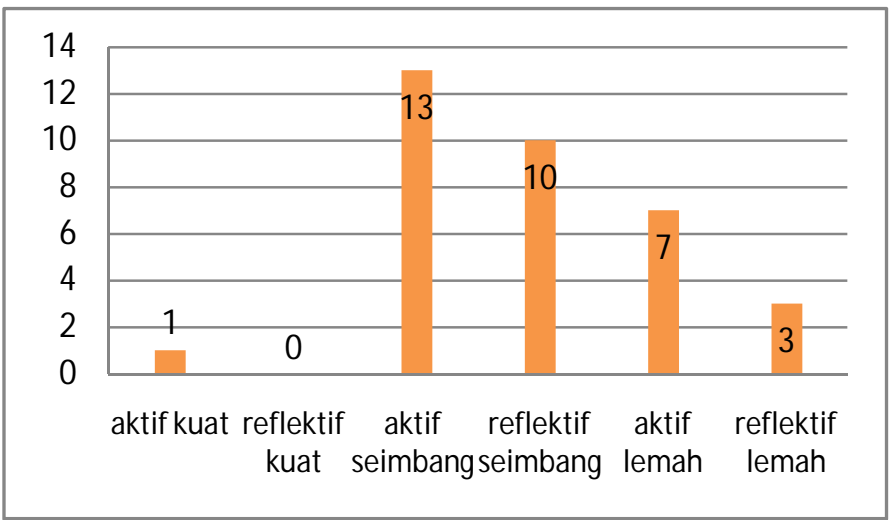

Gambar 1. Profil Gaya Belajar Siswa
Berdasarkan Gambar 1 diperoleh bahwa gaya belajar dominan siswa kelas XI MIA 7 SMAN 1 Manyar adalah gaya belajar aktif reflektif seimbang. Siswa bergaya belajar aktif-reflektif seimbang cenderung membutuhkan kedua gaya belajar ini. Pembelajaran aktif dilakukan dengan mengajak siswa untuk melakukan percobaan yang dapat memancing keaktifan siswa dan memberikan waktu untuk merefleksikan konsepkonsep yang telah diperoleh (7).

\section{Keterlaksanaan Pembelajaran}

Analisis dilakukan untuk mengetahui kesesuaian antara langkah-langkah pembelajaran yang dilakukan dengan sintaks yang terdapat dalam RPP. Sintaks yang digunakan pada penelitian ini adalah sintaks inkuiri, sehingga siswa dapat aktif dalam mengikuti pembelajaran dengan melakukan percobaan yang berkaitan dengan faktor-faktor yang mempengaruhi laju reaksi. Pembelajaran inkuiri memiliki tahapantahapan yang sesuai untuk melatihkan keterampilan berpikir kritis dengan pola nested.Analisis keterlaksanaan ditunjukkan pada Gambar 2.

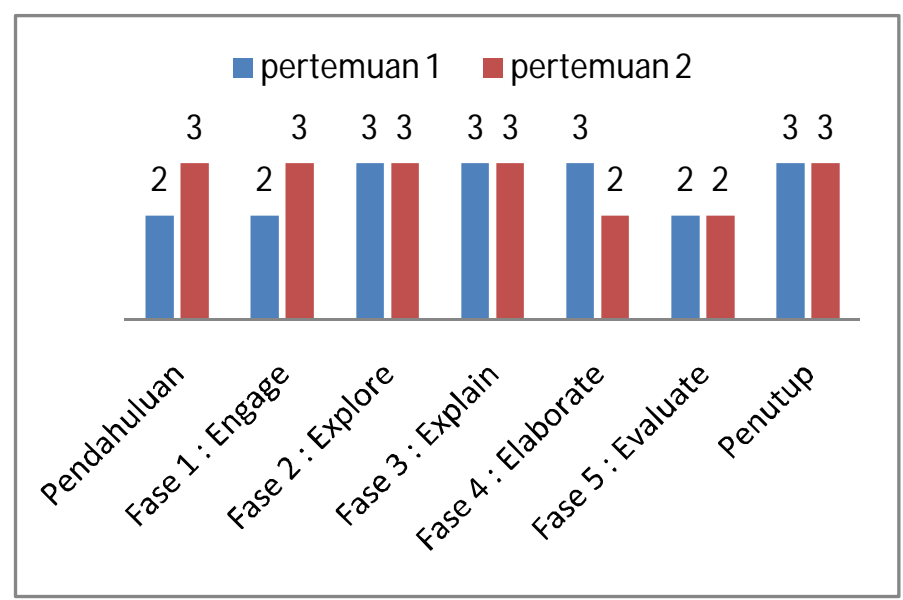

\section{Gambar 2 Analisis Keterlaksanaan Pertemuan 1 dan Pertemuan 2}

Berdasarkan Gambar 2, diketahui terdapat beberapa fase yang mengalami peningkatan nilai pada pertemuan kedua, seperti pada fase pendahuluan dan fase engage. Hal ini dikarenakan pada pertemuan kedua siswa lebih aktif dalam menyampaikan pendapatnya berkaitan dengan interpretasi fenomena yang berkaitan dengan faktor-faktor laju reaksi dibandingkan pada pertemuan pertama.

Pada fase 4: elaborate, nilai keterlaksanaan mengalami penurunan. Pada fase ini siswa dihadapkan kembali dengan fenomena baru, kemudian siswa diminta menjawab pertanyaan pada LKS secara individu. Tahap ini dirancang untuk memberikan layanan bagi siswa bergaya 
belajar reflektif. Oleh sebab itu, guru sebagai peneliti merancang tahap ini untuk dikerjakan secara individu. Namun pada pertemuan kedua, waktu yang tidak memadai menyebabkan soalsoal pada tahap tersebut dibahas bersama oleh guru dan siswa.

\section{Keterampilan Berpikir Kritis}

Kemampuan berpikir kritis diukur sebelum dan sesudah pembelajaran laju reaksi dengan penataan kurikuler nested. Tujuan tes awal untuk mengetahui kemampuan atau keterampilan berpikir kritis siswa sebelum mengikuti pembelajaran laju reaksi dengan penataan kurikuler nested. Hasil tes awal kemudian nantinya dibandingkan dengan hasil tes akhir untuk mengetahui pengaruh pembelajaran laju reaksi dengan penataan kurikuler nested terhadap kemampuan berpikir kritis siswa. Kemampuan berpikir kritis pada penelitian ini terdiri dari empat komponen yaitu: interpretasi, inferensi, eksplanasi, dan evaluasi. Hasil pretestdan posttestuntuk kemampuan berpikir kritis ditunjukkan pada Gambar 3.

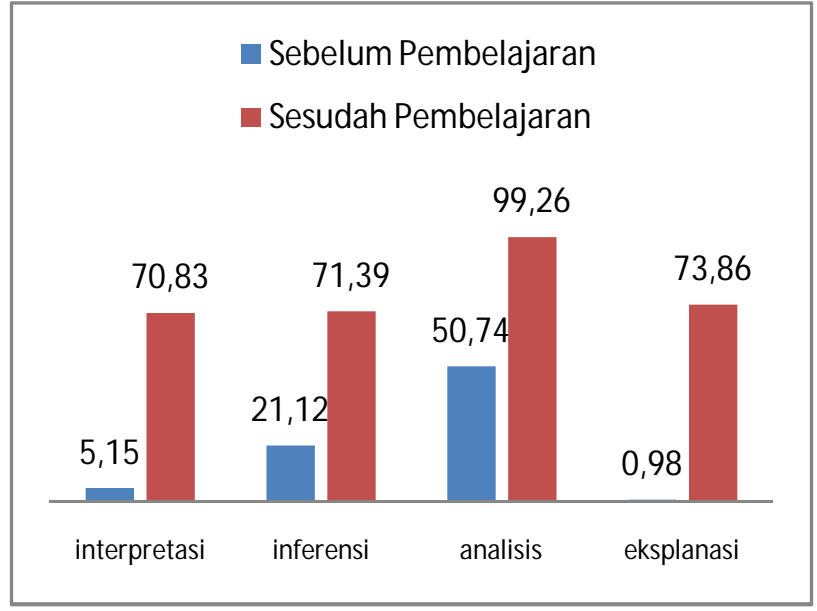

Gambar 3 Profil Kemampuan Berpikir Kritis Siswa BergayaBelajarAktif-Reflektif

Berdasarkan Gambar 3 diperoleh bahwa pretest keterampilan berpikir kritis siswa di kelas XI MIA 7 SMAN 1 Manyar masih sangat rendah. Selain itu, kemampuan berpikir kritis siswa didominasi oleh kemampuan analisis dengan persentase sebesar $50,74 \%$, sedangkan tiga kemampuan lainnya memperoleh persentase yang rendah. Hal ini menandakan bahwa siswa masih mengalami kesulitan dalam mengidentifikasi masalah dan membuat rumusan masalah yang menunjukkan kemampuan interpretasi. Selain itu, siswa juga masih kesulitan dalam menjelaskan argumen-argumen yang merupakan kemampuan eksplanasi. Hal ini ditandai dengan persentasenya yang sebesar 0,98\%. Kemampuan eksplanasi pada penelitian ini diukur dengan menggunakan soalsoal yang disajikan dalam bentuk fenomena yang berkaitan dengan faktor laju reaksi dan siswa diminta untuk menjelaskan kaitannya dengan faktor tersebut. Sedangkan kemampuan interferensi adalah kemampuan untuk menentukan variabel dan kesimpulan. Kemampuan analisis adalah kemampuan untuk menguji data, mengidentifikasi, dan menganalisis argumenargumen. Soal-soal analisis pada penelitian ini dibuat dalam bentuk fenomena dan siswa diminta untuk mengidentifikasi faktor laju reaksi yang berkaitan dengan fenomena tersebut.

Berdasarkan Gambar 3 diketahui bahwa hasil tes untuk keterampilan berpikir kritis mengalami peningkatan dibandingkan sebelum mengikuti pembelajaran. Selain itu, persebaran keterampilan berpikir kritis hampir seimbang di setiap kemampuannya. Hasil pretest dan posttest kemudian dipakai untuk menguji hipotesis dengan menggunakan uji-t. Uji-t dilakukan dengan bantuan SPSS.

Berdasarkan analisis yang telah dilakukan, diketahui bahwa nilai $t$ hitung $=26,991$ dengan nilai $\alpha=0,05$ dan $n=34$. Nilai $t$ hitung yang diperoleh kemudian dibandingkan dengan nilai $\mathrm{t}$ tabel. Nilai $\mathrm{t}$ tabel $=2,042$. Berdasarkan hasil tersebut diketahui bahwa, nilai $\mathrm{t}$ hitung $\geq \mathrm{t}$ tabel, hal ini menunjukkan adanya peningkatan keterampilan berpikir kritis.

\section{Pemahaman Konsep Siswa}

Tes awal dan tes akhir juga dilakukan untuk mengukur pemahaman konsep siswa. Nilai hasil belajar siswa ditunjukkan pada Gambar 4 .

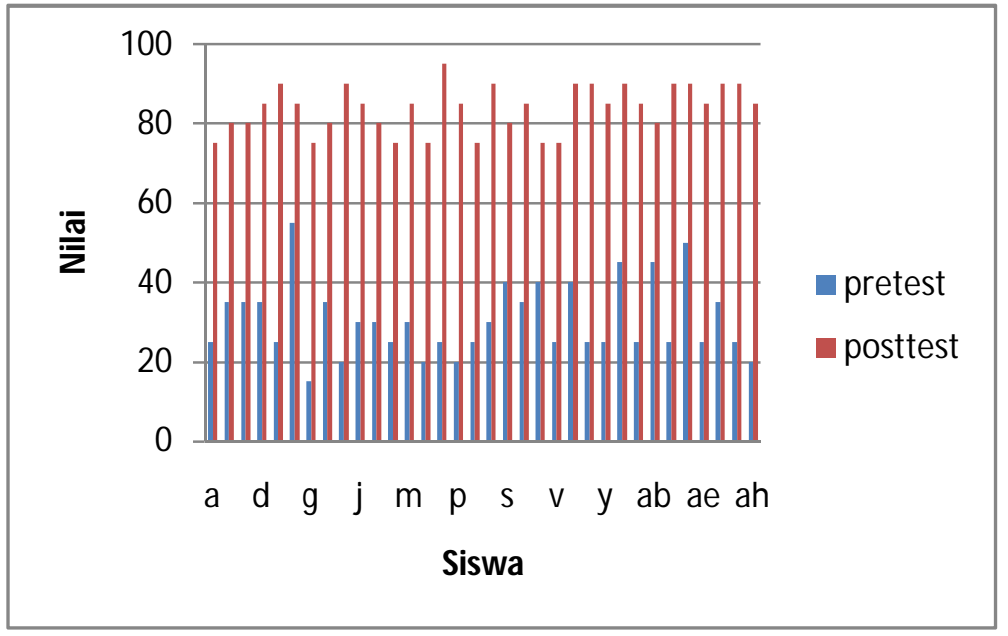

\section{Gambar 4 Profil Pemahaman Konsep Siswa Bergaya Belajar Aktif-Reflektif}

Berdasarkan Gambar 4 diperoleh bahwa terdapat peningkatan nilai hasil belajar siswa setelah mengikuti pembelajaran laju reaksi dengan 
penataan kurikuler nested. Hasil pretestdan posttest kemudian dipakai untuk menguji hipotesis dengan menggunakan uji Wilcoxon karena data yang diperoleh tidak berdistribusi normal. Uji Wilcoxon dilakukan dengan bantuan aplikasi SPSS.

\section{SIMPULAN DAN SARAN}

\section{Simpulan}

Simpulandari hasil penelitian dan pembahasan diperoleh bahwa terdapat perbedaan rerata nilai keterampilan berpikir kritis dan pemahaman konsep siswa bergaya belajar aktif-reflektif setelah mengikuti pembelajaran laju reaksi dengan penataan kurikuler nested, dimana nilai tes awal dan tes akhir keterampilan berpikir kritis dan pemahaman konsep siswa mengalami peningkatan. Hasil ini menunjukkan bahwa pembelajaran yang dirancang dapat berpengaruh terhadap keterampilan berpikir kritis dan pemahaman konsep siswa pada konten faktorfaktor yang mempengaruhi laju reaksi.

\section{DAFTAR PUSTAKA}

[1] Brotosiswojo. 2011. Hakekat Pembelajaran MIPA dan Kiat Pembelajaran Kimia di Perguruan Tinggi. Jakarta: Depdiknas.

[2] Putri, One Oktavianing \& Nasrudin, Harun. 2018. Penerapan Model Pembelajaran Kooperatif Tipe Numbered Heads Together (NHT) UntukMelatihkanKeterampilan Proses Sains Peserta Didik Pada Materi Kesetimbangan Kimia Kelas XI MAN Kota Mojokerto. Surabaya: UNESA Journal of Chemical Education.

[3] Kemendikbud. 2016. Salinan Lampiran Permendikbud Nomor 24 Tahun 2016 tentang Kompetensi Inti dan Kompetensi Dasar. Jakarta: Kemendikbud.

[4] Sugiyono. 2010. Metode Penelitian Pendidikan (Pendekatan Kuantitatif, Kualitatif, dan $R \& D)$. Bandung: Bandung:Alfabeta.

[5] Riduwan. 2015. Variabel-variabel Penelitian. Bandung : Bandung:Alfabeta.
Berdasarkan analisis yang telah dilakukan, diketahui bahwa, nilai Asymp Sig $=0.00$. Hal ini menandakan bahwa nilai Asymp Sig<0,05. Hal ini dapat disimpulkan bahwa terdapat peningkatan pemahaman konsep pada siswa bergaya belajar aktif-reflektif setelah mengikuti pembelajaran laju reaksi dengan penataan kurikuler nested.

Saran

Berdasarkan hasil penelitian ini, untuk meningkatkan kualitas implementasi menjadi sangat baik terdapat hal-hal yang perlu diperbaiki diantaranya pengaturan waktu dan keterlaksanaan pembelajaran pada setiap fase, serta proses pembagian kelompok yang perlu memperhatikan kemampuan dari tiap siswa/siswi. Saran yang diberikan peneliti untuk peneliti ke depannya adalah pembelajaran kimia dengan penataan kurikuler nested sangat cocok untuk melatihkan keterampilan berpikir kritis siswa. Oleh sebab itu, dapat digunakan pada materi kimia lain yang memiliki karakteristik sama seperti pada laju reaksi

[6]Hake, Richardz. R. 1998. Analyzing Changeor Gain Scores.

[7] Hudah, Miftahul. 2011. Cooperative Learning. Yogyakarta : Pustaka Belajar.

[8] Rohmah, Datin Mufidhatur \& Nasrudin, Harun. 2015. Implementasi Model Pembelajaran Kooperatif Tipe Numbered Head Together (NHT) Untuk Melatihkan Keterampilan Berpikir Kritis Siswa Pada Materi Stokiometri Di SMAN3 Lamongan. Surabaya: UNESA Journal of Chemical Education. Vol. 42.

[9] Lati, Wichai, Supasornn, Saksri\&Promarak, Vinch. 2012. Enhancement Of Learning Achievement andInte grated Science Process Skills Using Science Inquiry Learning Activies Of Chemical Reaction Rates. 44714475, s.l. : Sciversi SCIENCE DIRECT Procedia - Social Behavioral Sciences.

[10] Ibrahim. 2000. Pembelajaran Kooperatif. Surabaya: Surabaya: UNESA-University Press. 